
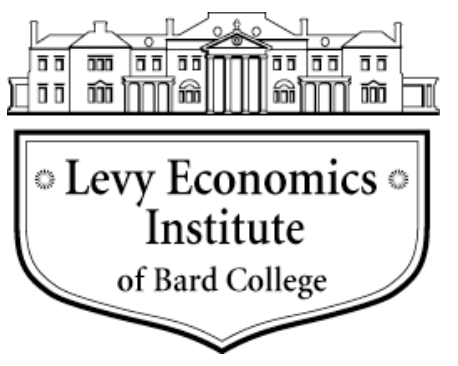

Working Paper No. 604

\title{
Three Futures for Postcrisis Banking in the Americas: The Financial Trilemma and the Wall Street Complex
}

By

\author{
Gary A. Dymski*
}

June 2010

* Department of Economics, University of California, Riverside, Riverside CA 92521-0427, USA. E-mail: gary.dymski@ucr.edu. The author thanks participants in the 2009 Red Nacional conference "Globalización Financiera y Desarrollo Sustentable," La Paz, Baja California Sur, Mexico, October 13-15, 2009, and especially coordinators Eugenia Correa, Alicia Girón, Arturo Guillén, and Antonina Ivanova for their insightful comments on an earlier version of the ideas contained herein.

The Levy Economics Institute Working Paper Collection presents research in progress by Levy Institute scholars and conference participants. The purpose of the series is to disseminate ideas to and elicit comments from academics and professionals.

Levy Economics Institute of Bard College, founded in 1986, is a nonprofit, nonpartisan, independently funded research organization devoted to public service. Through scholarship and economic research it generates viable, effective public policy responses to important economic problems that profoundly affect the quality of life in the United States and abroad.

\author{
Levy Economics Institute \\ P.O. Box 5000 \\ Annandale-on-Hudson, NY 12504-5000 \\ http://www.levyinstitute.org
}




\section{ABSTRACT}

This would seem an opportune moment to reshape banking systems in the Americas. But any effort to rethink and improve banking must acknowledge three major barriers. The first is a crisis of vision: there has been too little consideration of what kind of banking system would work best for national economies in the Americas. The other two constraints are structural. Banking systems in Mexico and the rest of Latin America face a financial regulation trilemma, the logic and implications of which are similar to those of smaller nations' macroeconomic policy trilemma. The ability of these nations to impose rules that would pull banking systems in the direction of being more socially productive and economically functional is constrained both by regional economic compacts (in the case of Mexico, NAFTA) and by having a large share of the domestic banking market operated by multinational banks.

For the United States, the structural problem involves the huge divide between Wall Street megabanks and the remainder of the U.S. banking system. The ambitions, modes of operation, and economic effects of these two different elements of U.S. banking are quite different. The success, if not survival, of one element depends on the creation of a regulatory atmosphere and set of enabling federal government subsidies or supports that is inconsistent with the success, or survival, of the other element.

Keywords: Banking; Financial Crisis; Trilemma; Wall Street; Mexico; United States; Financial Regulation; Megabanks; Regional Compacts; NAFTA

JEL Classifications: E5, F3, G1, G2, O1, P5 


\section{INTRODUCTION}

Since 2007, the crisis of the U.S. financial system, which has led to the deepest crisis of global finance since the 1930s, has monopolized business news worldwide. If we take a more historical perspective, however, we are quickly forced to recognize that banking systems have been in crisis in the one part of the Americas or another during most of the last 30 years: the disintermediation crisis and massive deregulation of U.S. banks in 1980; the 1982 Latin American debt crisis; the U.S. savings-and-loan crisis; the 1994-95 Tequila crisis; the 1998 Long-term Capital Management (LTCM) crisis and its fallout; the Argentine crisis of 2001; the “sudden stop" of foreign financial inflows to Latin America in 2002; and now the 2007 subprime crisis, whose impacts are still being felt.

At this point, the United States and Mexico are suffering the lingering effects of banking crises, especially in terms of bad loans and banks' failure to meet credit demand. ${ }^{1}$ Prior to the subprime crisis, the response of international financial institutions-especially the International Monetary Fund (IMF) - to financial crisis in the Americas (elsewhere than in the United States) was predictable: open markets, regulate better, eliminate fiscal deficits. Postcrisis, however, the IMF has indicated a willingness to be flexible (Ambrose 2009). Thus, this would seem an opportune moment to reshape banking systems in the Americas that have failed, drawing on the example set by banking systems such as Brazil's that, by all accounts, are financially healthy and economically productive.

Any effort to rethink and improve banking must acknowledge three major barriers. The first is a crisis of vision. It is easy to develop a long list of the problems of banking systems that have failed, but what kind of banking system will work best for any national economy?

The other two constraints are structural. This structural problem for banking systems in Mexico and the rest of Latin America takes the form of a financial regulation trilemma, the logic and implications of which are similar to those of the macroeconomic policy trilemma that smaller nations confront in the global economy. The ability of these nations to impose rules that would pull banking systems in the direction of being more socially productive and economically

\footnotetext{
${ }^{1}$ On U.S. banks' problems with bad loans, see Mason (2010); on their failure to lend after the crisis which has been extensively covered in the business press, see Enrich, Crittenden, and Tamman (2009). On the nonperforming loans in Mexico, see Business News Americas (2009); on lags in lending in Mexico's banking system, see Pineda (2009).
} 
functional is constrained both by regional economic compacts (in the case of Mexico, NAFTA) and by having a large share of the domestic banking market operated by multinational banks.

For the United States, the structural problem involves the huge structural divide between Wall Street megabanks and the remainder of the U.S. banking system. The ambitions, modes of operation, and economic effects of these two different elements of U.S. banking are quite different. The success—if not survival—of one element depends on the creation of a regulatory atmosphere and set of enabling federal government subsidies or supports that are inconsistent with the success or survival of the other element. These constraints are severe and make it clear that the challenge of creating financially healthy and economically productive banking systems throughout the Americas is daunting. However, only by confronting these challenges can the possibility of truly responsive financial systems arise.

\section{THE ABSENCE OF AN ALTERNATIVE VISION OF FINANCIAL SYSTEM FUNCTIONING}

As noted above, the frequent financial crises that have afflicted one or another part of the Americas has provided many opportunities for considering anew what the economic functions of banks are and how best banking can be organized to carry out these functions.

In the postwar period through the mid-1960s, discussions of this kind were grounded in an economic development literature that acknowledged national economies' unique financial institutions and markets, each the product of a distinct history (Gerschenkron 1962). In the mid1960s, the reference point for discussions of banking shifted toward adoption of the core concepts of the efficient-market hypothesis, then emerging in finance theory. The basic premise of this approach is that one size fits all: specifically, financial markets are most efficient in allocating available resources when flows of credit and capital among wealth-holders, debtors, and financial intermediaries are given complete freedom of choice about how and where to borrow and/or to invest. This vision, of course, is embedded in the World Bank and IMF's models of how financial markets should work; it provides a benchmark for how these markets should be reformed when crises afflict them. ${ }^{2}$

\footnotetext{
${ }^{2}$ For references to the literatures referred to here, see Dymski (2006).
} 
For the United States, with the presence of aggressive megabanks on Wall Street that were continually developing innovative spot, futures, and derivatives markets, the consensus of most financial economists was that eliminating regulatory barriers domestically and abroad would maximize both U.S. banks' global position and national welfare. Saunders and Walter (1994) wrote, for example:

\begin{abstract}
"Overall, we suggest that barriers to market access, whether geography- or market-based, erode the static and dynamic efficiency and global competitiveness of the U.S. financial system and its contribution to national economic welfare. The barriers also erode the financial system's stability, by limiting financial institutions' access to capital and their ability to effectively diversify exposures and profit streams, thereby placing the taxpayer at risk ... the existing U.S. bank regulatory structure seems to embody a triple threat to the national interest in being comparatively inefficient, uncompetitive, and unsafe, all at the same time.” (page vi).
\end{abstract}

This sentiment was, in effect, broadly embraced by many monetary economists, under the sway of efficient-market thinking. Not coincidentally, the formation of compacts such as the European Monetary Union (EMU), the North American Free Trade Agreement (NAFTA), and the World Trade Organization (WTO), all involved shifts toward financial openness, and hence to entry by overseas firms (among which U.S. firms were often first in line). The many financial crises during the neoliberal period also led to agreements, often reached under force, that opened markets. Not coincidentally, large Wall Street firms moved into the lead in numerous areas of "global financial services," and indeed the Wall Street megaplex became seen as a key source of competitive advantage for the United States (Franko 2004).

In the 1980s, many economists became interested in the implications of asymmetric information in credit (and other) markets, since the presence of asymmetric information precludes the attainment of first-best equilibrium in financial (or other) markets. Economists, such as Stiglitz (2002), asserted that developing economies' financial systems would function better when public authorities made decisions that avoided moral-hazard traps in credit and capital markets, but more economists pointed to ways in which government-controlled credit allocation was likely to result in moral-hazard (and adverse selection) problems. So when these economies experienced crises, economists tended to look for the source of the problems in 
asymmetric-information linked violations of efficient markets allocations. Thus, privatizing public banks, eliminating state planning agencies and development banks, and opening financial and banking markets to foreign entry were standard responses to crises.

The notion that financial crises represented either punishments for systems prone to moral-hazard abuses or implosions for countries with unsustainable macroeconomic policies was eventually set aside. Experiences of financial crises in apparently "virtuous" countries suggested even to IMF-affiliated economists that financial crises could arise because of sunspots. ${ }^{3}$ Economists studying Latin American banking and finance came to the realization that the completely boundaryless world of efficient-market theory, in which investors immediately recognize and fund the virtuous, was not the world they lived in. Recently, even economists inclined to accept the notion that market efficiency should guide decision-making have demonstrated caution. For example, Cavallo and Izquierdo (2009) warn about the need to guard against "sudden stops" in capital or credit flows to Latin America- "stops" unrelated to fundamentals. Chortareas, Garza-Garcia, and Girardone (forthcoming) worry about whether the banking concentration that has arisen in many Latin American countries from years of crisis and foreign entry has subjected financial consumers to market power. In a World Bank volume, de la Torre and Schmukler (2007) describe the results of decades of reform and the opening of Latin American capital markets as “disappointing.” They argue that policy analysts' suggestions can be summarized by two statements: "be patient and redouble the effort" or "get the sequence right.” Frustrated by what they regard as the fruitless to-and-fro between proponents of these views, they advocate a third approach, "revisit basic issues and reshape expectations."

These authors' conclusion goes right to the heart of the basic problem. Analysts have become increasingly skeptical of the premises of the efficient-market approach and all of its warnings about moral-hazard traps when allocation mechanisms take account of market imperfections, rigidities, and even national development priorities. But this slow stepping away from efficient markets has not been accompanied by the embrace of an alternative vision of how socially productive and economically functional financial markets could be organized. There are many examples of alternatives, often involving social banks, microfinance, cooperatives, and so on. Discussions of these alternatives tend to focus in on the specifics of particular institutional frameworks and/or to limit their scope to subquestions such as using financial mechanisms to

\footnotetext{
${ }^{3}$ This is the essential idea of the "second-generation model” of currency crises; see Dymski (2006).
} 
address poverty. ${ }^{4}$ Further, there are no ongoing debates about alternative approaches that make public allocations of capital and credit to targeted industrial sectors, that use tax or other incentives to affect private institutions' credit/capital allocation outcomes, and/or that provide planning and guidance for the financing of national investment. Economists who favor market allocation assume these alternatives have been shown to be fatally flawed, success stories like Brazil’s National Bank for Economic and Social Development (BNDES) notwithstanding; economists who support such alternatives have usually, again, focused on specific cases without examining analytically the roles they play in the broader functioning of national finance. When alternatives to an efficient-market vision of a banking system are discussed, this is done only fleetingly or in a very general, nonspecific way.

In sum, while the subprime crisis surely demonstrated that the Wall Street megaplexbased financial system of the United States has become dysfunctional, subsequent discussion has focused only on how this existing system might be better regulated (less leverage, more transparency, etc.). There has been no debate among politicians or economists about the elements - much less the merits and flaws — of an alternative approach to financial system design. This lacuna is much easier to grasp once it is understood that an alternative has not been fully imagined.

\section{THE FINANCIAL TRILEMMA}

When an alternative vision of how banking might function in one of the nations of the Americas is identified, the immediate questions are: how much autonomy of action and control is there for any nation, and how has it been affected by the global financial and economic crisis?

Autonomy is problematic for every American nation other than the United States. Just as most nations are subject to the Mundell-Fleming “trilemma,” most financial systems are now subject to a bank-regulation “trilemma” due to hierarchical global rules about financial regulation.

To see this, let's begin with the familiar case. During the neoliberal era, virtually all Latin American financial systems have experienced one or more crises linked to the Mundell-Fleming trilemma. According to this set of postulates, a country cannot simultaneously maintain

\footnotetext{
${ }^{4}$ See, for example, Armendariz de Aghion and Morduch (2005).
} 
independent monetary policy, stable exchange rates, and financial integration with the rest of the world. Financial crises, IMF intervention, and changing domestic balances of political power led many Latin American economies away from rejecting financial integration and toward financial integration. The trilemma then dictates that either domestic monetary policy or exchange rate stability must be sacrificed.

Many developing nations have attempted to gain control over this trilemma by building up huge volumes of foreign reserves. ${ }^{5}$ The response to the trilemma then depends on the strength of reserves and control over all the mechanisms of monetary policy, including banks' behavior in domestic markets. But this, in turn, brings us to another set of constraints that has not been previously recognized in the many elaborations and extensions of the Mundell-Fleming thesis.

In principle, every nation is free to choose bank regulations. Postcrisis policy interventions in developing nations have assumed as much; after both the Latin American and Asian financial crises, the IMF promoted “better regulation” as a universal antidote against future financial crises. The implication is that any nation, even in the global South, is free to shape financial regulations as it wishes, but if it does this badly, calamity can result. However, the reality is different.

National authorities' regulations and enforcement about what banks can do is constrained by two factors. The first is whether this nation is in a regional compact, such as the EMU or NAFTA, for regional compacts typically impose uniformity and market-entry rules on participating nations' financial systems. A second key factor is whether foreign megabanks have significant shares of a given nation’s banking market. If so, these megabanks' behavior is constrained primarily by the rules of the Basle system and these banks’ own home-nations’ banking authorities. While megabanks may comply with domestic rules about loan-making and financial-service provision, their overall strategies will be dictated elsewhere-and, of course, these large banks may attempt to attain exceptions to local rules on fair-competition grounds.

So this is another type of trilemma: a nation cannot simultaneously be in an integrated regional compact, have a large share of its market occupied by foreign megabanks, and freely make its own financial rules and regulations.

Further, this trilemma works one way for financial-center countries and another way for

\footnotetext{
${ }^{5}$ Among the recent papers exploring this phenomenon are Aizenman, Chinn, and Ito (2008) and Obstfeld, Shambaugh, and Taylor (2008).
} 
developing nations. Financial-center nations can dictate the scope of action for their megabanks, insist on harmonization for foreign banks operating domestically, and police the remainder of their system as they please. Developing nations’ regulatory options are constrained by the behavior permitted to the megabanks operating within their borders. Efforts to regulate more strictly will be met by threats of retaliation or departure. In effect, in nations outside of financial centers, compensation for risk must replace regulation of risk.

\section{THE U.S.'s FINANCIAL DILEMMA: REGULATING TWO DISPARATE BANKING SYSTEMS}

If the financial trilemma affects Mexico and other nations in Latin America, the United States has its own financial dilemma. ${ }^{6}$ This dilemma arises because of regulatory and operational tensions between the megabank and community bank subsectors within the U.S. financial structure.

The United States entered the neoliberal era with a large banking population; there were 14,434 commercial banks insured by the Federal Deposit Insurance Corporation (FDIC) as of December 1980. This large population, of course, reflects the unique historical development of the United States - as it expanded sequentially, on a state-by-state basis, every state shaped a financial sector responsive to its own growth and industrial character. This decentralized pattern also permitted excessive risk-taking, so an equally peculiar regulatory structure emerged to limit risks. With the election of the promarket Reagan Administration, regulatory policy turned in favor of mergers as a way of encouraging more banking efficiency, as discussed above (Dymski 1999). In the 27 years prior to 1982, an annual average of 150 U.S. commercial banks disappeared through nonassisted mergers; in the 27 years from 1982 to 2008, this average rose to 419 per year. In December 1979, the United States had 14,364 FDIC-insured commercial banks; in September 2009, it had 6,911—a decline of 52\%.

Restrictions on banks' activities and on their expansion across intranational borders were reduced or eliminated, both by administrative action and new legislation. Large banks were not immune to the merger wave. To the contrary, occasional financial crises and flawed regional

\footnotetext{
${ }^{6}$ We do not discuss the case of Canadian banking here, but see Li, Dymski, and Oberle (2009). Canada's banks, having avoided the equity losses that afflicted most large banks in Europe and the United States, are currently expanding across borders (Mason 2009).
} 
expansion strategies during the neoliberal era led to the consolidation of many of the largest U.S. banks. For example, of the twenty-four largest BHCs in the United States as of 1997, only thirteen still existed in 2004; the remainder were eliminated by nonassisted mergers (two with foreign-owned banks). By September 2009, only ten of these banks remained.

Furthermore, the very largest banks in the U.S. banking hierarchy became larger even relative to other large banks. In December 1997, the average asset size of the three largest bank holding companies (BHCs)—Citibank, Bank of America, and Chase—equaled just over 300\% of the asset size of the other banks included among the U.S.'s top 24 BHCs; in June 2008-before investment banks and other nonbanks were classified as bank holding companies-this figure for the (same) three largest BHCs had climbed to over $800 \%$. This "gigantification" is due both to these largest BHCs' moving more forcefully than smaller banks to take over small commercial banks (and their deposit bases) and to these institutions' expansion into investment banking, broker-dealer activity, and/or insurance.

This latter expansion, of course, combined with other competitive shifts, put these large BHCs into direct competition with large nonbank Wall Street firms. Of course, this competition eventually encompassed the bundling, holding, and sale of subprime paper and of CDOs. Once the subprime crisis hit home, U.S. banking was suddenly transformed. For in 2008, three of the five largest Wall Street noncommercial bank firms either failed or disappeared through merger (Lehman Brothers, Merrill Lynch, Bear Stearns); the other two were converted into BHCs. Consequently, as of December 2009, six megabanks—Bank of America, JP Morgan Chase, Citibank, Wells Fargo, Goldman Sachs, and Morgan Stanley—stand alone as the commanding heights of U.S. banking.

While the 2008 Troubled Asset Relief Program (TARP) program that preserved these megabanks' existence provoked a huge outcry, it is important to note that TARP was consistent with the broader design of U.S. banking policy. After all, the U.S. government provided subsidies for large banks to buy failed savings-and-loan associations after the 1980s "thrift" crisis and then encouraged their transformation to megabanks through a series of financial deregulation acts. Of course, Wall Street lobbyists—as did the largest commercial bankspushed hard for financial deregulation, which permitted financial firms with the requisite sophistication, scale, and customer bases to expand into a new set of fee-generating activities. In effect, the emergence of the six largest U.S. megabanks through the eventual intersection of Wall 
Street and supersized commercial banks should be understood not as an accidental byproduct of the 2007-08 subprime crisis, but as the endpoint of a lengthy period of intentional policy choices regarding the activities and market scope of a reshaped, more efficient U.S. banking industry. What was unintended was that the final emergence of these more efficient megabanks should have required such huge public interventions to survive crises of their own making. That said, megabanks' dominance in the government financial bailout - their disproportionate share of TARP funds—continued a policy design begun three decades earlier.

What was perhaps also not intended was that the United States, at the end of 30 years of a bank merger wave, would have two essentially distinct banking sectors, for paralleling the megabanking sector is a community banking sector that is dominated by small banks; over nine of every ten U.S. banks have under $\$ 1$ billion in assets.

The question immediately arises whether large and small banks in the United States differ in important ways. Some contrasts can be drawn using balance sheet data. One important contrast involves the source of revenue: banks under $\$ 1$ billion in assets derive about threequarters of their income from interest, whereas interest income and non-interest (fee-based) income have been approximately equal in larger banks. ${ }^{7}$ In some other areas—such as nonperforming loans as a share of all loans and net profits per dollar of assets-small banks and other banks' performance is quite similar. Where a clear contrast emerges is in the extent of risktaking related to off-balance-sheet activities. As figure 1 shows, banks below $\$ 1$ billion in assets have virtually no derivatives exposure; by contrast, the issuance of derivatives by banks above $\$ 1$ billion in assets has climbed steadily, reaching nearly 2,000\% of assets, on average, in 2008.

\footnotetext{
${ }^{7}$ These data are taken from the author's calculations using data from the FDIC and from the federally maintained National Information Center.
} 
Figure 1: Derivatives as a Percent of Assets, 1992-2008: Small ( $<\$ 1$ Billion in Assets) vs. Big ( $>$ \$1 Billion in Assets) Banks

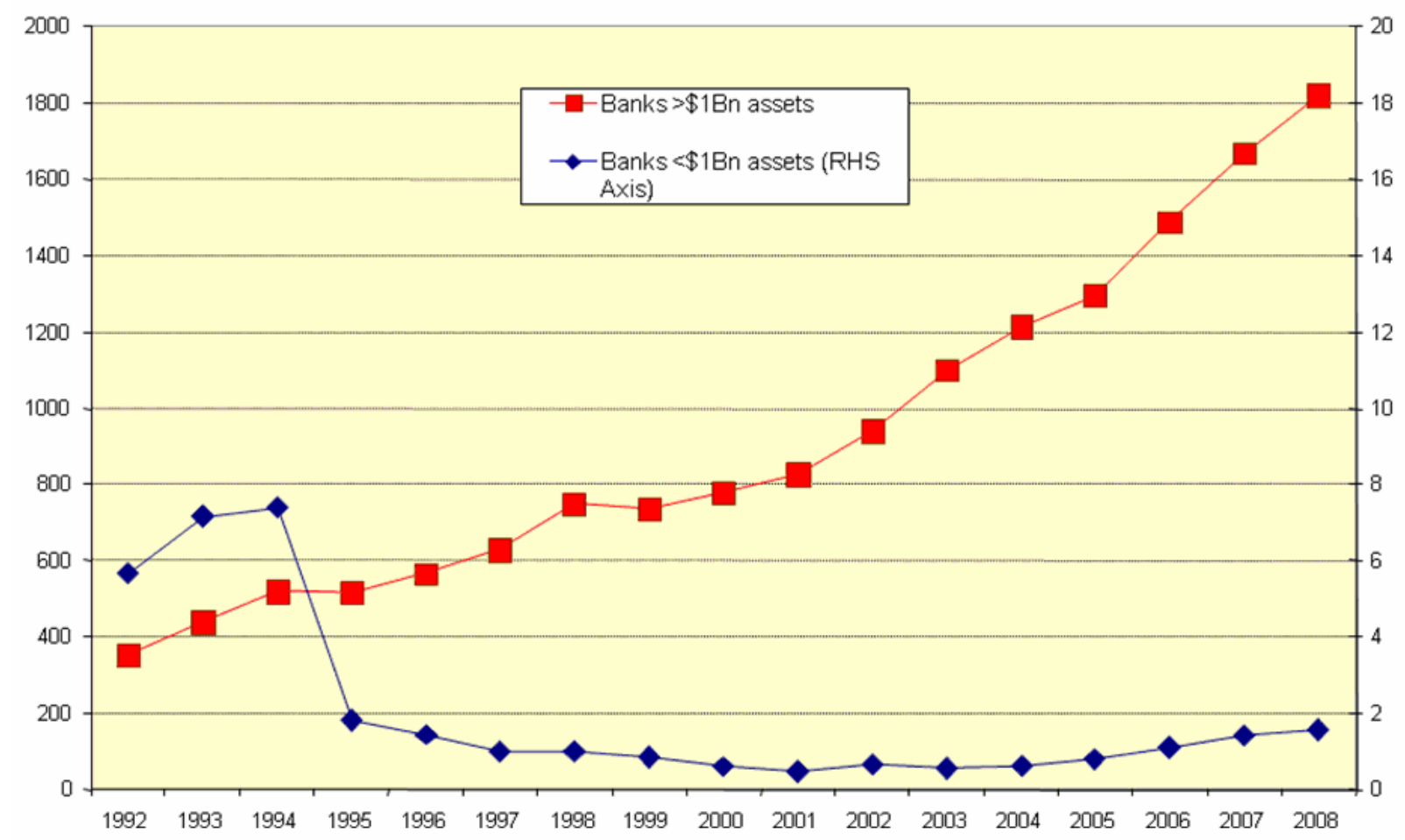

Further, banks with under $\$ 1$ billion in assets have engaged in virtually no loan securitization, as figure 2 illustrates; by contrast, loan sales with recourse-which means that loan purchasers can seek compensation from issuers if the loans they have bought perform poorly-have climbed above 30\% for larger banks. 
Figure 2: Loans Scrutinized with Recourse as a Percent of All Loans, 2001-2008: Small ( $<\$ 1$ Billion in Assets) vs. Big ( $>\$ 1$ Billion in Assets) Banks

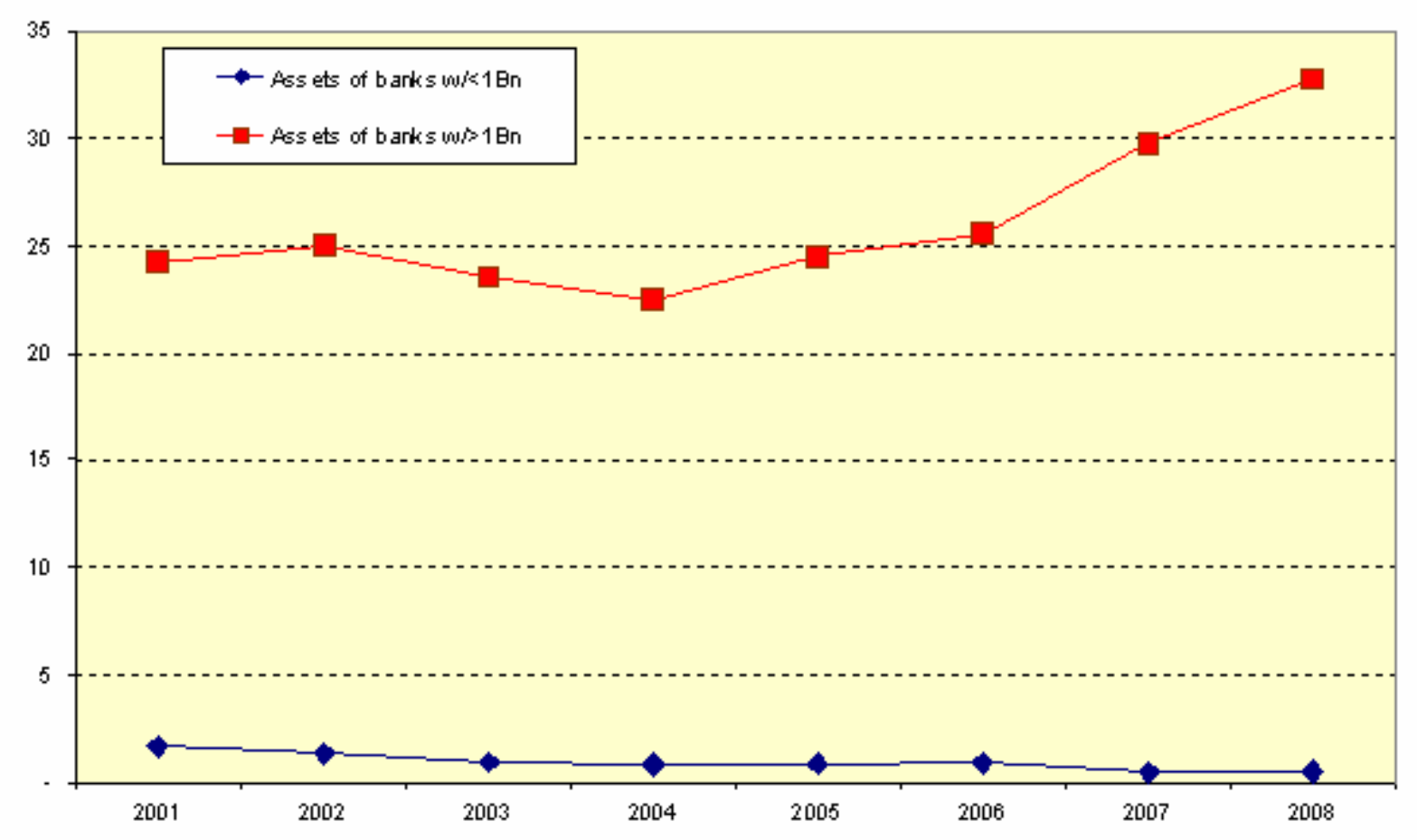

The contrasts go further, however. Smaller banks’ business models depend on local economies - on local circuits of business activity, housing construction, and employment. By contrast, megabanks' business models depend on fee-based activity, securitization, and offbalance-sheet position-taking in global finance circuits. So the profitability of local banks depends on maintaining the vitality of local economic spaces, while the profitability of megabanks depends on identifying new targets for fee- or margin-generating activities.

This brings us to the U.S. banking dilemma. It was, famously, the megabanking sector with its extensive securitization activities that required a massive bailout and which has essentially been positioned as “too big to fail.” But then there is a mismatch between social functionality and subsidy, as the part of the banking system that participates in local social functioning and supports small businesses without other means of finance, is unprotected. Rather, the part of the banking system that is abstracted from the local economy and provides few services to small businesses is the recipient of direct and indirect subsidies (respectively, TARP and the Federal Reserve's purchase at book value of large volumes of suspect commercial paper and securitized mortgages over the past two years). As stressed above, the result of this 
unbalanced use of subsidies and bailouts, and of the three-decade-long merger policy, is that an ever larger share of banking markets are held by larger banks. Figure 3 shows that the larger banks' dominance of off-balance-sheet activity is increasingly mirrored in on-balance-sheet activity.

Figure 3: Share of Bank Markets Held by Banks over \$1 Billion, 1992-2008

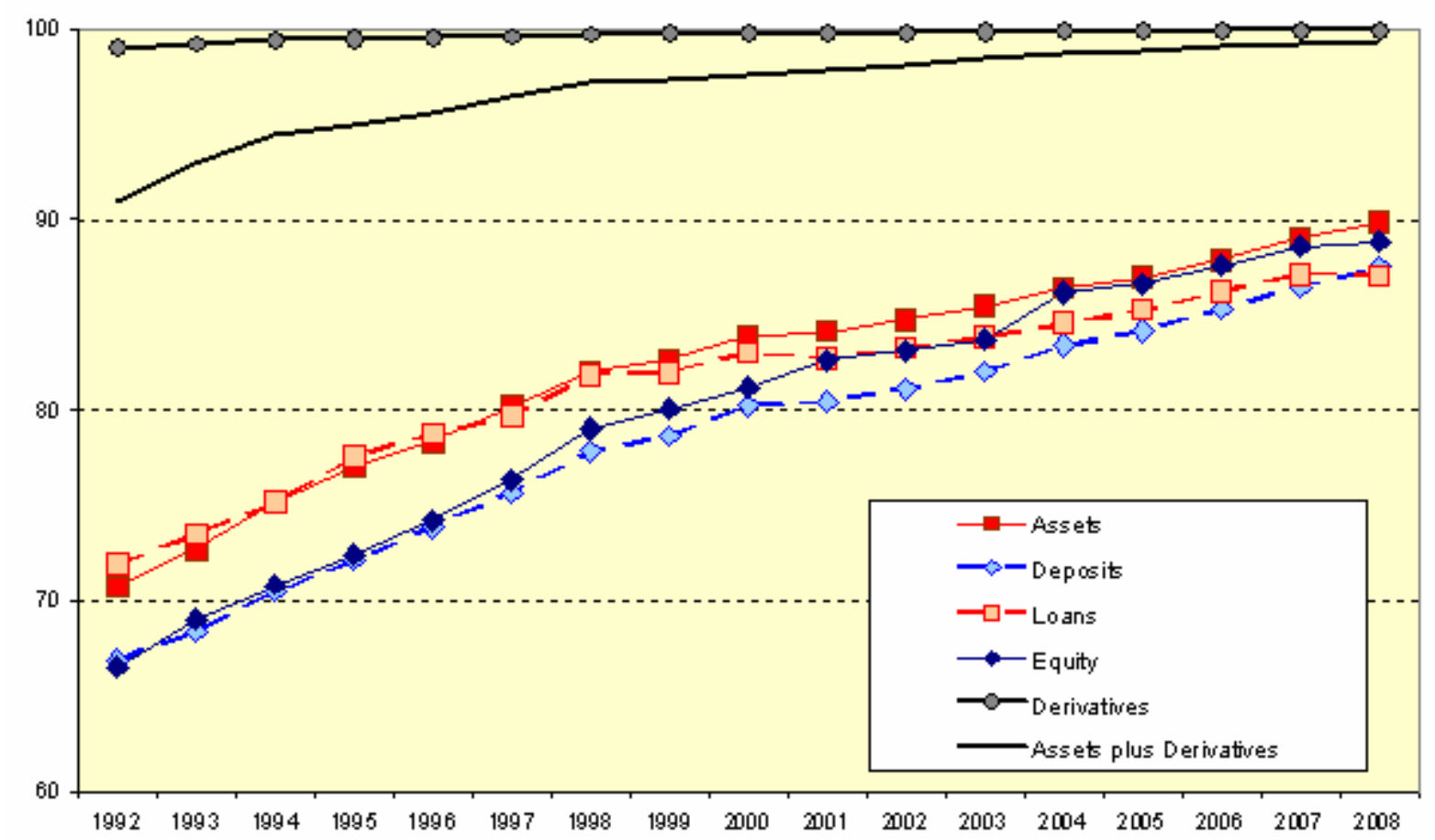

It should be noted that while this dilemma reflects elements that are unique to the United States, other countries face similar dilemmas. Domestically owned megabanks also receive “special treatment” as domestic champions in the UK and the EU; elsewhere, as noted above, overseas banks operating locally often receive special treatment. Considerations of this kind then set up tensions involving the allocation of subsidies and of market access with other, less favored portions of the financial sector. Which "redundant" banks are caught in a "squeeze" differ from country to country. In many nations, contrasts emerge between two categories of banking firms: smaller financial institutions serving local markets, often with little public support and with the need to behave conservatively and megabanks, focused on serving global markets—and often focused on global expansion—with strong public support, especially in times of crisis. 


\section{THREE FUTURES FOR BANKING IN THE AMERICAS}

The constraints highlighted here- the lack of imagination in experts' thinking about what banking is, together with asymmetric structures of power in global and national financial systems - threaten to create narrow boundaries for the future of financial reform in the Americas.

As a thought experiment, we set out three different futures here. We then briefly evaluate the social and economic functionality or dysfunctionality of each alternative, and speculate about the policy and behavioral pathways that might lead toward one or another of these futures.

In one possible future, the U.S. and European megabanks that dominate their home markets will compete fiercely for market share in emerging markets, including Latin America. Not all megabanks are the same; consider, for example, the differences in Citibank's and Santander's experience of the subprime crisis. This said, offshore megabanks could conceivably attempt to carve out portions of Latin American markets.

Some national spaces within Latin America will see intense rivalry in many financial markets and product lines. Here, Mexico has led the way, with Brazil and Argentina close behind. These countries' consumer banking markets offer desirable targets because of the size, income, and wealth of the population. For parallel reasons, other markets are less attractive. Unless a new regional compact opens up space for one-size-fits-all banking products, other nations will see less foreign-bank entry with fewer financial products.

So in this future, Latin America emerges as one site of a struggle for global megabank supremacy. This struggle might also encompass the future of the dollar in the global economy.

A second future imagines Latin America as the site of an intensifying global competition for scarce resources (such as petroleum, water, and food) and hence for global income share. Then relatively resource-deprived countries will scour the globe even more intently than now to meet their requirements. Here China comes immediately to mind. In tandem with resourceseeking, Asian banks—-perhaps led by Chinese banks—will aggressively enter Latin American markets, alongside the U.S. and European banks already there.

If this future comes to pass, the focus of financial entry will be quite different than above. There, domestic economic units provided the impetus. Here, resource-seeking nations' banks would likely emphasize crossborder flows of capital and credit, not the establishment of Latin American branch networks. In this event, Latin America would become one hub of a global 
competition for power and hegemony.

A third future proceeds differently. It begins with the possibility of reconstructing banking and finance on a socially and economically functional basis. Banking in the Americas could be shaped to serve national and regional development needs, based on goals such as the equalization of wealth and opportunity. Policymakers could then freely consider such questions as whether microcredit should be expanded, whether access to transactions accounts should be universalized, whether new consumer financing instruments are welfare-enhancing or exploitative, and whether a state development bank like Brazil's BNDES is needed to finance critically needed investment. The question then becomes whether the existing financial structure can achieve these goals; if not, changes in institutions or incentives are needed.

This way of thinking about finance is not well-developed for several reasons. First, it would require renewing a "developmentalist” approach to finance-and, as argued above, this would require rediscovering ways of thinking about the economic role of banking and finance that have been nearly lost since the 1960s. Second, it would require some modification of regional-compact rules that establish rights of market access for nondomestic financial firms.

These three potential futures may not be mutually exclusive. Elements of each might unfold, with points of tension where these views of banking collide. In the United States, the social-accountability requirements rooted in the 1977 Community Reinvestment Act (CRA) are certainly at odds with megabanks' “caveat emptor” approach to financial-service provision. ${ }^{8}$ In Brazil, the developmentalist agenda of BNDES coexists with the customer-market-expansion agenda of the nation's private (and semipublic) banks; the tension between the resourceextraction approach to finance and the developmentalist approach was illustrated in 2008 when China insisted that Brazil provide trade credit through BNDES for its own soy exports.

\section{CONCLUSION}

The utter breakdown of so many of the world's largest financial firms in the 2007-08 global financial crisis provides a good opportunity for thinking anew about the economic functions and social impacts of banking and finance. If another world of banking and finance is possible, apart

\footnotetext{
${ }^{8}$ Indeed, we can suppose that the allegations made during the subprime crisis that the CRA forced banks to make or hold so many bad loans represents, in part, an effort to shift the balance toward weaker social accountability requirements.
} 
from the Wall-Street-led system that just broke down so spectacularly, what would that world look like? This paper has briefly sketched out three possible futures for banking and finance in the Americas. One highlights a contest for consumer and business financial services markets, especially in the more populous or wealthy countries of the Americas. A second highlights the use of finance as an adjunct to a global struggle for resources, in which the Americas will invariably be involved. A third suggests the possibility of a future that begins with some agreement on the economic goals and social functions that financial institutions should meet, recommending policy changes where these are needed to meet these goals.

For any nation in the Americas, any effort at improving the functioning of banking by rethinking its purposes must acknowledge and respond to barriers to change. This paper has cited three. The first is a crisis of vision: a confusion among experts between how finance can operate in ideal, abstract settings and the operations of real-world financial systems. The many crises of finance have provided stark reminders that the idealized and real worlds of financial flows are very different. Nonetheless, for many, the habit of thinking as if efficient financial markets would emerge if only regulators would permit sufficient access to markets is deeply engrained.

The second constraint identified here was termed the financial-regulation trilemma. Specifically, any nation's ability to create rules that make banking systems more socially productive and economically functional is limited by the existence of regional economic compacts and by the presence in many domestic banking markets of large multinational banks.

The United States, in turn, faces another sort of constraint, described here as involving a Wall Street/community banking dilemma. That is, the U.S.'s Wall Street complex operates very differently than its community banks in terms of risks taken, the way loans are made, and so on. A dilemma arises insofar as the regulations, subsidies, and guarantees needed for the success of the Wall Street complex, which has been dominant until now in U.S. financial policymaking, are very different from a regulatory atmosphere that will encourage renewed vigor for U.S. community banks.

The immensity of the challenge of creating truly functional financial systems in the face of the constraints described here is clear-so clear that the exercise of imagining the third future may seem useless. This third possible future is included in this list precisely to make the point that such a future can only take shape as a reality if those who wish for it give it the same force that has been given to analyses of financial-system malfunction. What sequence of steps could 
bring us from the present state of financial-system malfunction and nonresponsiveness to a different future with socially responsive, economically functional finance? No matter how improbable it seems, this journey has to be thought before it can be walked. 


\section{REFERENCES}

Ambrose, Soren. 2009. “IMF Reforms: Mere Tinkering or Change We Can Live With?” Foreign Policy in Focus. Washington, DC: Institute for Policy Studies, September 17. Accessed at:

http://www.fpif.org/articles/imf_reforms_mere_tinkering_or_change_we_can_live_with on January 13, 2010.

Aizenman, Joshua, Menzie D. Chinn, and Hiro Ito. 2008. “Assessing the Emerging Global Financial Architecture: Measuring the Trilemma’s Configurations over Time.” Working Paper 14533. Cambridge, MA: National Bureau of Economic Research (NBER).

Armendariz de Aghion, Beatriz, and Jonathan Morduch. 2005. The Economics of Microfinance. Cambridge, MA: The MIT Press.

Business News Americas. 2009. "Mexican banks: Picking up the pieces as the crisis wanes.” Financial Services Intelligence Services, October. Accessed at: http://member.bnamericas.com on January 12, 2010.

Cavallo, Eduardo, and Alejandro Izquierdo. 2009. "Dealing with the crisis: Lessons from Latin America," Posted on Voxeu.org, March 28. Accessed at: http://www.voxeu.org/index.php?q=node/3358 on January 13, 2010.

Chortareas, Georgios E., Jesus G. Garza-Garcia, and Claudia Girardone. Forthcoming. “Banking Sector Performance in Latin America: Market Power versus Efficiency." Review of Development Economics 30.

de la Torre, Augusto, and Sergio L. Schmukler. 2007. Emerging Capital Markets and Globalization: The Latin American Experience. Washington, DC: The World Bank (copublished with Stanford Economics and Finance).

Dymski, Gary A. 1999. The Bank Merger Wave: The Economic Causes and Social Consequences of Financial Consolidation in the United States. Armonk, NY: M.E. Sharpe.

—. 2006. "Banking and Financial Crises.” in Philip Arestis and Malcolm Sawyer (eds.), Handbook of Alternative Monetary Economics. Cheltenham, UK: Edward Elgar.

_. 2010. "Understanding the Subprime Crisis: Institutional Evolution and Theoretical Views.” Mimeo. University of California, Riverside, January 5.

Enrich, David, Michael R. Crittenden, and Maurice Tamman. 2009. “Bank Lending Keeps Dropping.” Wall Street Journal, April 20. 
Franko, Lawrence G. 2004. "U.S. Competitiveness in the Global Financial Services Industry.” Working Paper 1001. Boston: Financial Services Forum, College of Management, University of Massachusetts Boston.

Gerschenkron, Alexander. 1962. Economic Backwardness in Historical Perspective: A Book of Essays. Cambridge, MA: Harvard University Press.

Li, Wei, Gary Dymski, and Alex Oberle. 2009. "Global Banking and Financial Services to Immigrants in Canada and the United States." Journal of International Migration and Integration 10(1): 1-29.

Mason, Christopher. 2009. “Canada’s Banks Poised for Global Growth.” Financial Times, December 8.

Mason, Joseph. 2010. “The Outlook for 2010: Bank Failures and Bank Losses Ahead.” posted on the Roubini Global Economics website, January 12. Accessed at: http://www.roubini.com/latam-monitor/258156/ on January 12, 2010.

Obstfeld, Maurice, Jay C. Shambaugh, and Alan M. Taylor. 2008. "Financial Stability, the Trilemma, and International Reserves.” Working Paper 14217. Cambridge, MA: National Bureau of Economic Research (NBER).

Pineda, Javier Guillermo Gomez. 2009. "Whither the Credit and Asset Price Cycle in Latin America?” posted on the Roubini Global Economics website, December 21. Accessed at: http://www.roubini.com/latam-monitor/258156/ on January 12, 2010.

Sachs, Jeffrey. 2009. "Rethinking Macroeconomics.” Capitalism and Society 4(3), Article 3. Web-published by www.bepress.com.

Saunders, Anthony, and Ingo Walter. 1994. Universal Banking in the United States: What Could We Gain? What Could We Lose? New York: Oxford University Press.

Stiglitz, Joseph E. 2002. Globalisation and Its Discontents. New York: Norton. 